\title{
Adequate timing for heart-of-palm harvesting in King palm.
}

\author{
Marilene L.A. Bovi; Luiz Alberto Saes; Roberta Pierry Uzzo; Sandra H. Spiering \\ Instituto Agronômico, C. Postal 28, 13.001-970 Campinas - SP. e-mail: mlabovi@cec.iac.br
}

\begin{abstract}
Heart-of-palm, palm heart, or "palmito" can be considered as a non-conventional vegetable, largely consumed in Brazil and exported to more than sixty countries. Timing of heart-of-palm harvesting is a critical issue in palmito agribusiness, since it affects yield, quality and costs. A three-year field experiment was utilized to identify the correct timing for king palm heart-of-palm harvesting, from the standpoint of maximizing yield and minimizing growing period. The experimental site was located at Pariqueraçu, Vale do Ribeira, a region where palmito agribusiness has increased recently, due to adequate climatic conditions, low costs and high industry demand. Crop was grown in $2 \times 0.75 \mathrm{~m}$ spacing, utilizing six-month old seedlings. Growth was assessed periodically by measuring plant diameter and height (from soil level to insertion of leaf spear), as well as leaf number and size. Harvest was done, from 36 to 40 months after planting date. The results showed high plant variability, a common feature in palm. In spite of genetic variability, the adequate timing for start heart-of-palm harvesting (considering plant growth rate, yield, quality and market type), was reached when palms were 80 to $115 \mathrm{~cm}$ (small diameter) and 200 to $300 \mathrm{~cm}$ tall (large diameter). The time to attain those heights varies widely among plants and growing conditions. In this experiment, harvesting could be started at 22 months after planting.
\end{abstract}

Keywords: Archontophoenix alexandrae, palmito, growth, yield, quality.

\section{RESUMO}

Determinação de estádio adequado para colheita de palmito de palmeira real australiana.

Palmito é uma hortaliça não convencional, largamente consumida no Brasil e exportada para mais de sessenta países. A determinação do tempo adequado para sua colheita é fundamental para o agronegócio palmito, visto que afeta produção, qualidade e custos. Um experimento a campo, com três anos de idade, foi utilizado para identificar o ponto adequado de colheita de palmito da palmeira real australiana de forma a maximizar produção e minimizar tempo de cultivo. A área experimental está localizada em Pariqueraçu, Vale do Ribeira (SP), uma região em que o agronegócio palmito vem crescendo recentemente devido às condições climáticas adequadas, baixos custos e alta demanda pelas indústrias locais. $\mathrm{O}$ cultivo foi feito no espaçamento de 2 × $0,75 \mathrm{~m}$ utilizando mudas com seis meses de idade. $\mathrm{O}$ crescimento das plantas foi avaliado periodicamente, medindo-se diâmetro e altura (do solo até a inserção da folha flecha), bem como número e comprimento de folhas. A colheita foi feita entre 36 e 40 meses após o plantio. Os resultados mostraram grande variabilidade entre plantas, característica comum em palmeiras. Apesar da variabilidade genética, concluiu-se que o ponto adequado para começar a colheita de palmito (considerando taxa de crescimento, produção, qualidade e tipo de mercado) tem início quando as plantas atingem altura de 80 a $115 \mathrm{~cm}$ (palmito de pequeno diâmetro) e 200 a $300 \mathrm{~cm}$ (para diâmetros maiores). O tempo necessário para atingir essas alturas varia grandemente entre plantas e entre condições de cultivo. Neste experimento a colheita poderia ter início 22 meses após o plantio.

Palavras-chave: Archontophoenix alexandrae, seafortia, crescimento, produção, qualidade.

\section{(Aceito para publicação em 25 de abril de 2001)}

$\mathrm{H}$ eart-of-palm can be harvested from different species of palms (Tabora et al., 1993). It is basically composed of the unexpanded leaves immediately above the apical meristem. Nowadays, also the soft apical portion of the stem (meristem downwards) has been utilized as palm heart, increasing yield (Codex Alimentarius, 1985). Heart-of-palm is commercialized either "in natura" or as canned food. The market for raw or unprocessed heart-of-palm is still incipient, restricted to large cities and based on local plantation production. Therefore, most of the heart-of-palm is processed and consumed as canned food, using standard practices (Berbari $\&$ Paschoalino, 1997). Even as a canned food, there are at least three markets for the product. The primary market is formed by heart-of-palm, with diameter varying from 2 to $3 \mathrm{~cm}$, processed in cans or jars with maximum $300 \mathrm{~g}$ drained weight. A second market type comprises heart-of-palms processed in large jars (1.200 to $1800 \mathrm{~g}$, drained weight), with diameter varying from 3 to $5 \mathrm{~cm}$ and is aimed to restaurants and hotels. A third market type comprises heart-of-palm and edible stem parts processed in slices, cubs or shredded, and packed in jars with drained weight varying from 240 to $1800 \mathrm{~g}$. It is a preserve used at home, hotels and restaurants in recipes where the product would be shredded (soups, pie fillings, quiches, etc). Independently of type and style, the overall product quality is a function of its chemical composition, as well as plant growth rate and some morphological features, as number and size of leaves and their components (Ferreira et al., 1982a,b; Bovi et al. 1992; Mora-Urpí et al., 1997).

Most of the heart-of-palm production comes from palms of the Euterpe genus. Due to wide natural distribution and high population density, the species Euterpe edulis Mart. and Euterpe oleracea Mart. have been exploited for this purpose in a predatory level. Both species are slow growing and attempts to cultivation had relative success, due to a series of technical, 
ecological, economical and social problems (Galetti \& Fernandez, 1998; Muniz-Miret et al., 1996; Orlande et al., 1996; Pena-Claros \& Zuidema, 1999). Large-scale palm plantations for heartof-palm production have been done, since 1990, utilizing fast growing species, mainly Bactris gasipaes Kunth (Bovi, 1997; Mora-Urpí et al., 1997). Although this palm has fast growth rate and clustering capacity, other species have been also prospected, especially those with heart-of-palm similar to the one produced by Euterpe edulis (Tabora et al., 1993). In fact, Archontophoenix species, an Australian palm, commonly known as King palm and worldwide utilized as ornamental (Jones, 1994; Lorenzi, 1996), have been recently cultivated in Brazil as a source of high quality heart-of-palm (Bovi, 1998).

There are some attributes related to heart-of-palm yield and quality that palm species must have. From the economical standpoint, palms elected to produce heart-of-palm should be fast growing, easily cultivated and efficient in biomass accumulation in response to mineral and/or organic amendments. From the product quality standpoint, their hearts-of-palm should be cylindrical, straight, light in coloration (whitish or light yellow) and free of toxic compounds or enzymes (or substrate where they acts) which promote oxidation and/or discoloration (Codex Alimentarius, 1985). Heart-ofpalm diameter is also important and dependent on consumer demand. As the major market is for heart-of-palm in cans or jars with maximum $300 \mathrm{~g}$ (drained weight), palm heart diameter should be 1.5 to $3.0 \mathrm{~cm}$, in order to be safely and easily packed and processed (Codex Alimentarius, 1985).

Heart-of-palm yield and dimensions are highly correlated with some vegetative traits, as plant diameter and height and number and size of leaves and leaflets. Easily measured traits, as diameter and height, have been commonly used in Euterpe and Bactris species to evaluate palm superiority in relation to growth and palm heart yield (Bovi et al., 1991a,b; Bovi et al., 1992). In those palm genera, it was reported that heart-of-palm harvesting time

Table 1. Correlation coefficients between vegetative and yield related traits for King palm grown (sample size $=238$ ). Pariqueraçu (Brazil), IAC, 2000

\begin{tabular}{lrrrrrrr}
\hline \multirow{2}{*}{ Traits } & \multicolumn{3}{c}{ Growth traits } & \multicolumn{4}{c}{ Yield components } \\
\cline { 2 - 8 } & PH & LN & LS & EW & HW & HD & HL \\
\hline Palm diameter (PD) & 0.89 & 0.64 & 0.84 & 0.73 & 0.71 & 0.75 & 0.47 \\
Palm height (PH) & & 0.68 & 0.82 & 0.74 & 0.72 & 0.70 & 0.52 \\
Leaf number (LN) & & & 0.53 & 0.59 & 0.53 & 0.56 & 0.35 \\
Leaf size (LS) & & & & 0.67 & 0.62 & 0.68 & 0.47 \\
Edible stem weight (EW) & & & & 0.55 & 0.61 & 0.40 \\
Heart-of-palm weight (HW) & & & & & 0.69 & 0.77 \\
Heart-of-palm diameter(HD) & & & & & & 0.48 \\
\hline
\end{tabular}

All coefficients were significant at $\mathrm{P}<0.001$. $\mathrm{PH}$ - palm height; $\mathrm{HL}$ - heart-of-palm length.

varied widely among species, being also dependent on climate, soil and management conditions (Ferreira et al., 1982a,b; Ferreira et al., 1990; MoraUrpí et al., 1997). Nonetheless, there were found no reports concerning heartof-palm yield and adequate timing of harvesting for the King palm, reason for that, this research was carried out.

\section{MATERIAL AND METHODS}

The trial was located in the Pariqueraçu Experimental Station (24ํㄱ' $\mathrm{S}, 4^{\circ} 53^{\prime} \mathrm{W}, 25 \mathrm{~m}$ above sea level), Sao Paulo, Brazil. The climate of the region is mesothermic, tropical, hot and humid, with average annual temperature of $22.1^{\circ} \mathrm{C}$, annual rainfall of $1519 \mathrm{~mm}$ and evapotranspiration of $1087 \mathrm{~mm}$ (Lepsch et al., 1990). The soil at the experimental area was classified as Fluvaquentic Dystrochrept (dystrophic Cambisol), with the following chemical properties at $0-20$ cm depth: $\mathrm{pH}\left(\mathrm{CaCl}_{2}\right) 4.1$, organic matter $30 \mathrm{~g} \mathrm{dm}^{-3}$, P $9 \mathrm{mg} \mathrm{dm}^{-3}, \mathrm{~K}^{+} 1.4$, $\mathrm{Ca}^{2+} 4, \mathrm{Mg}^{2+} 8, \mathrm{H}+\mathrm{Al}^{3+} 70 \mathrm{mmol} \mathrm{dm}^{-3}$, and $16 \%$ base saturation of the CEC at $\mathrm{pH}$ 7.0, determined by methods described by Raij et al. (1986).

Crop was planted in $2 \times 0.75 \mathrm{~m}$ spacing, utilizing 780 six-month old seedlings from a seed lot of Archontophoenix alexandrae Wendl. \& Drude, grown in $150 \mathrm{~cm}^{3}$ plastic containers, filled with commercial palm media. No limestone was applied to correct soil acidification. Superphosphate at a rate of $100 \mathrm{~g} /$ planting hole was applied. Mineral fertilization, $50 \mathrm{~g} / \mathrm{plant}$ of NPK (20:5:20), was provided every three months. Growth was assessed periodically by measuring plant diameter and height, as well as leaf number and length. Harvest was done from 36 to 40 months after planting, in 238 plants, selected at random, with heart of palm weight and size individually evaluated at each harvest following standardization according to Clement \& Bovi (2000). Additional vegetative traits were evaluated prior to harvesting. Growth and yield data were analyzed by regression and curve fitting, with response functions adjusted to the measured variables (Steel \& Torrie, 1980).

\section{RESULTS AND DISCUSSION}

Table 1 shows that heart-of-palm yield components (heart-of-palm and edible soft stem weight and dimensions) and vegetative traits, measured at harvesting time, were highly correlated $(\mathrm{P}<0.001)$, with coefficients varying from 0.53 (leaf number paired with leaf size) to 0.89 (plant diameter paired with plant height). The magnitudes of the coefficients were higher for plant diameter and height when paired with other growth and/or yield components. The easiness of measuring both traits, allowed to conclude that either one can be utilized to evaluate King palm growth and estimate palm yield. As plant height can be better visually estimated than palm diameter, we used it in the follow up discussion.

Plant growth, as assessed by periodical measurements of plant height, 


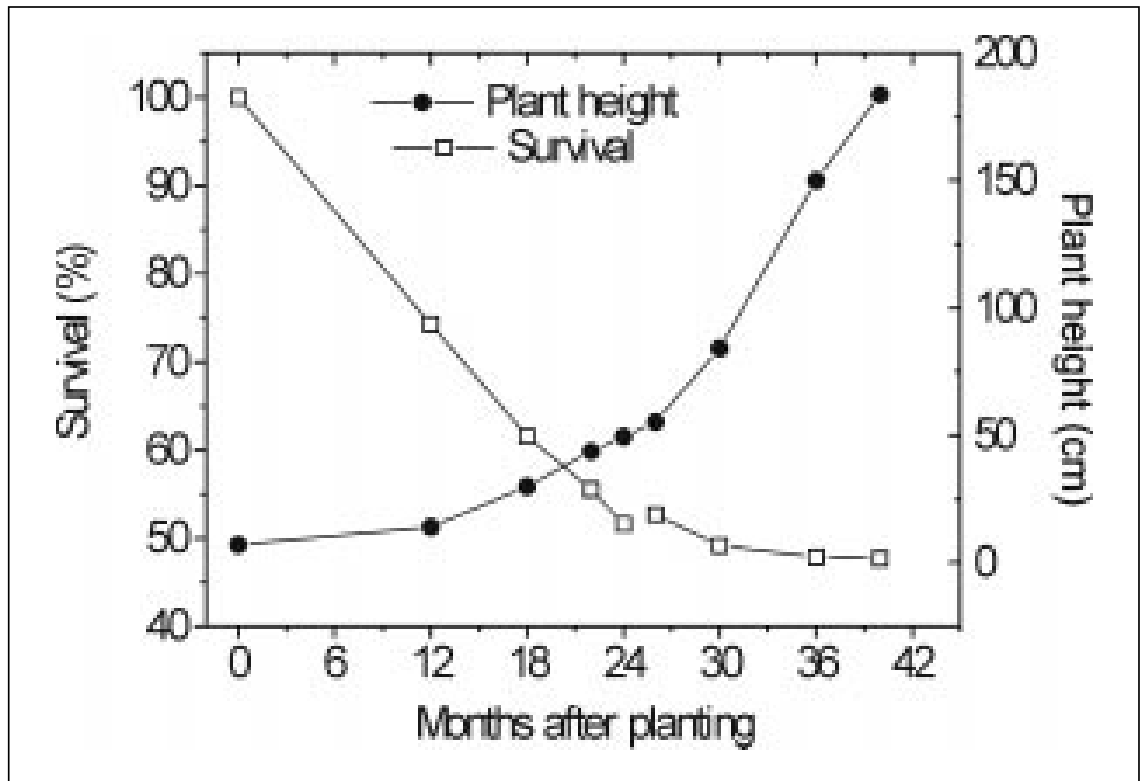

Figure 1. Average King palm plant height $(\mathrm{cm})$ and survival $(\%)$ along forty months after planting. Pariqueraçu (Brazil), IAC, 2000.

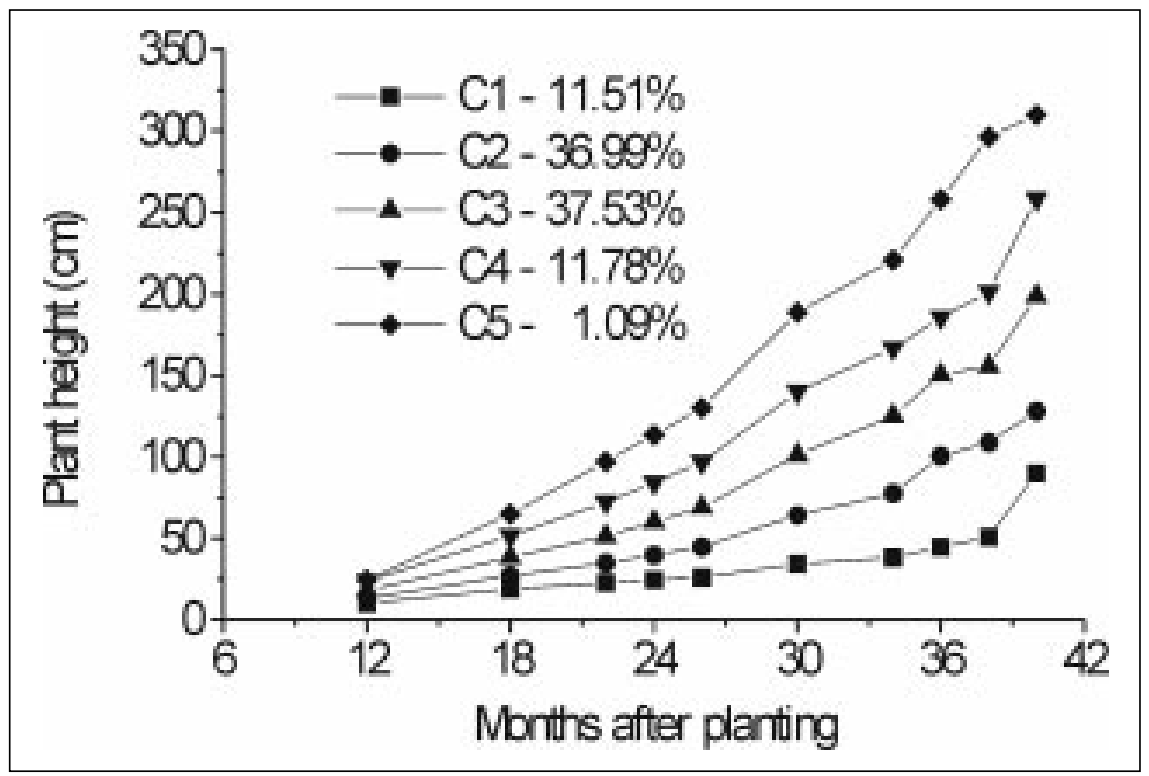

Figure 2. King palm variability as expressed by five classes of plant height. Pariqueraçú (Brazil), IAC, 2000.

was very slow until 12 months after planting (Figure 1). Nonetheless, slow growth was expected in these particular experimental conditions (seedlings established in small size containers, acid soil without limestone amendment, heavy initial grass competition). Besides slow growth, there was observed high mortality in the first year. Although there was a decrease in mortality as average plant height increased, plant survival at 40 months after planting was only $48 \%$ of the initial population. Slow growth and low survival often are closely related and have genetical and/or environmental origin (Hardon, 1982; Simmonds, 1979). They can be overcome by breeding and selection and also by applying adequate crop management (Hartley, 1977; Secretaria \& Maravilla, 1997).

Periodic growth evaluation, allowed to visualize large variability among plants, which let us classify the studied population in five classes in relation to plant height (Figure 2). Most of the plants (36.99 and 37.53\%) belong to classes 2 and 3, which comprised palms that were $101-150$ and $151-200 \mathrm{~cm}$ high, respectively, at 30 months after planting. Very slow growers were $11.51 \%$ of the population, whereas $12.87 \%$ belong to fast growers, with $1.09 \%$ composed by high stand plants.

Even considering the differences in classes, King palm growth showed to be slow, if compared to other palm species recognized to be precocious (Bovi et al., 1993; Tabora et al., 1993). The small initial differences in classes increased during the course of evaluation, reaching their maximum 38 months after planting. This among plant variability could be either genetical and/ or environmental in nature. Large genetic intra and inter population variability have been reported in palms by several authors (Clement, 1995; Hardon, 1982; Hartley, 1977; Secretaria \& Maravilla, 1997). Nonetheless, it is also known that vegetative traits have a strong environmental component and that palm responses to edaphical constraints are very effective (Hartley, 1977; Jorge \& Bovi, 1994; Bovi et al., 1997). Although the experimental area was apparently uniform, the presence of small spatial variations in soil physical and chemical proprieties cannot be disregarded (Souza et al., 1996).

It should be pointed out that even utilizing the same seed lot, with seedlings of the same age, cultivated under identical nursery and field conditions, there was observed a wide plant height variation presented in Figure 2. Therefore, the large variability, genetical and/or environmental, detected in the studied population, suggests that it is impossible to establish an adequate timing for heartof-palm harvesting in King palm based on chronological age. Instead, the results indicated that harvesting time should be based on plant development, with harvesting beginning over the most developed plants. The practice of selective harvesting is supposed to diminishes above and below ground competition among plants, with the possibility of dominate palms restart growth.

The best harvesting time in palm heart production should be decided taken in consideration several factors, as seasonal demand, market type, plant growth rate and climate. This last one is very important in non-irrigated 
plantations, since water is responsible for $90 \%$ of heart-of-palm fresh biomass (Ferreira et al., 1982a; Tabora et al., 1993). It was observed that, under dry weather, yield is lower and the palm heart has harder texture and is darker in color. Also, it should be reminded that, although the heart-of-palm weight increases along time (until a certain species specific size), it also increases the diameter, bringing problems for industrialization, difficulting the harvesting process, increasing the time in the field, raising plantation costs and consequent risks (plagues, diseases, herbivory, robberies, damages by wind, frost, etc). In addition, due to the nonclustering capacity of King palm, plantation should have large rotativity, with areas being liberated for new crops.

In order to establish the adequate plant size to start harvesting, it is necessary to taken in account weight and dimensions of the final product, since there are intricate relationships among them, which would reflect in quality.

In the present study there were considered two yield components: heartof-palm and edible soft stem. Although both are closely related to plant development (Table 1), they have similar, but no identical, responses (Figure 3). Heart-of-palm weight increased progressively with plant height $(\mathrm{Y}=$ $\left.11.163+0.739 x+0.005 x^{2}\right)$, meanwhile the edible apical stem weight showed a plateau starting at $200 \mathrm{~cm}$ plant height and later (after $250 \mathrm{~cm}$ ) a small decline $\left(\mathrm{Y}=-22.089+1.092 \mathrm{x}+0.014 \mathrm{x}^{2}-\right.$ $\left.0.000005 \mathrm{x}^{3}\right)$. As a fact, it was observed that faster grower palms have larger plant diameter and softer parenquimatous apical stem tissues, which comprises the edible stem portion.

Heart-of-palm dimensions are given by its diameter and length and especially the former is very important from the standpoint of correct processing and acidification. The relationships between plant height and heart-of-palm diameter and length can be visualized in Figure 4. A MMF model, with the equation $\mathrm{Y}=(-$ $\left.26.53+8.83 \mathrm{x}^{0.43}\right) /\left(6.40+\mathrm{x}^{0.43}\right)$, could describe palm heart diameter as a function of plant height. By the other hand, heartof-palm length followed a hyperbolic model $(\mathrm{Y}=30.03-857.96 / \mathrm{x})$, with a steepest increase until $100 \mathrm{~cm}$ height, and a tendency to reach a plateau with

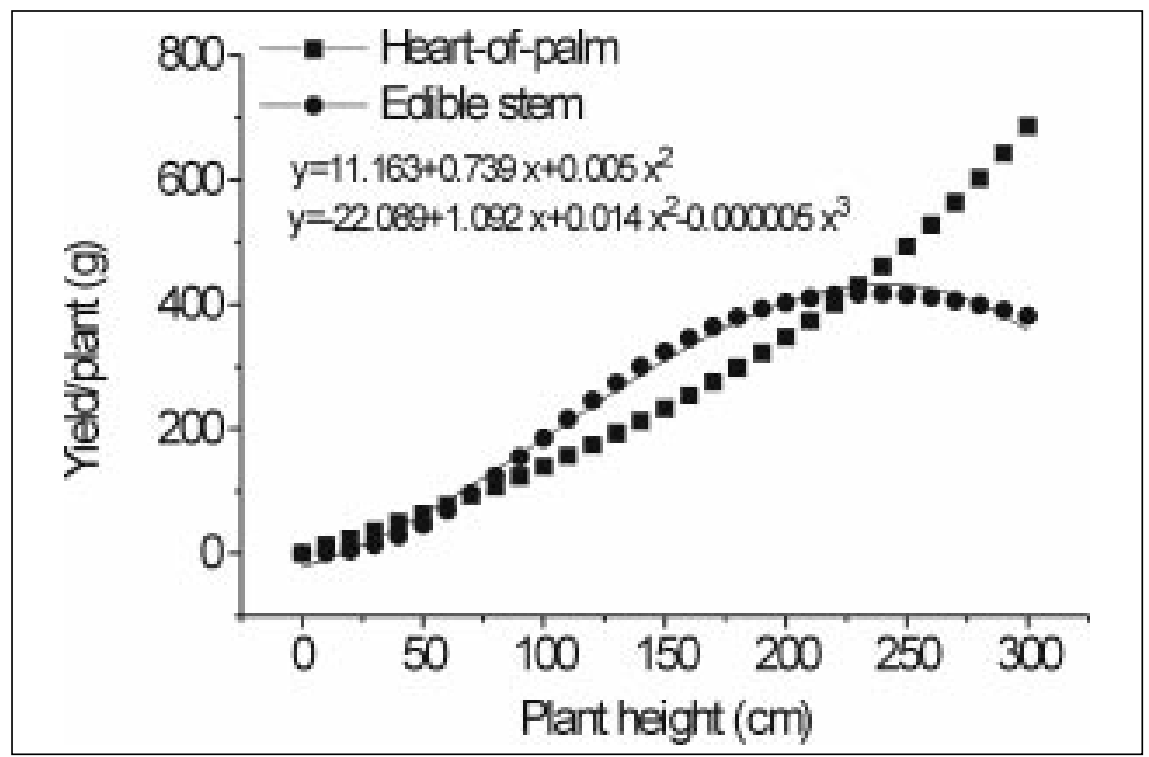

Figure 3. Heart-of-palm and edible stem yield of King palm as a function of plant height. Pariqueraçú (Brazil), IAC, 2000.

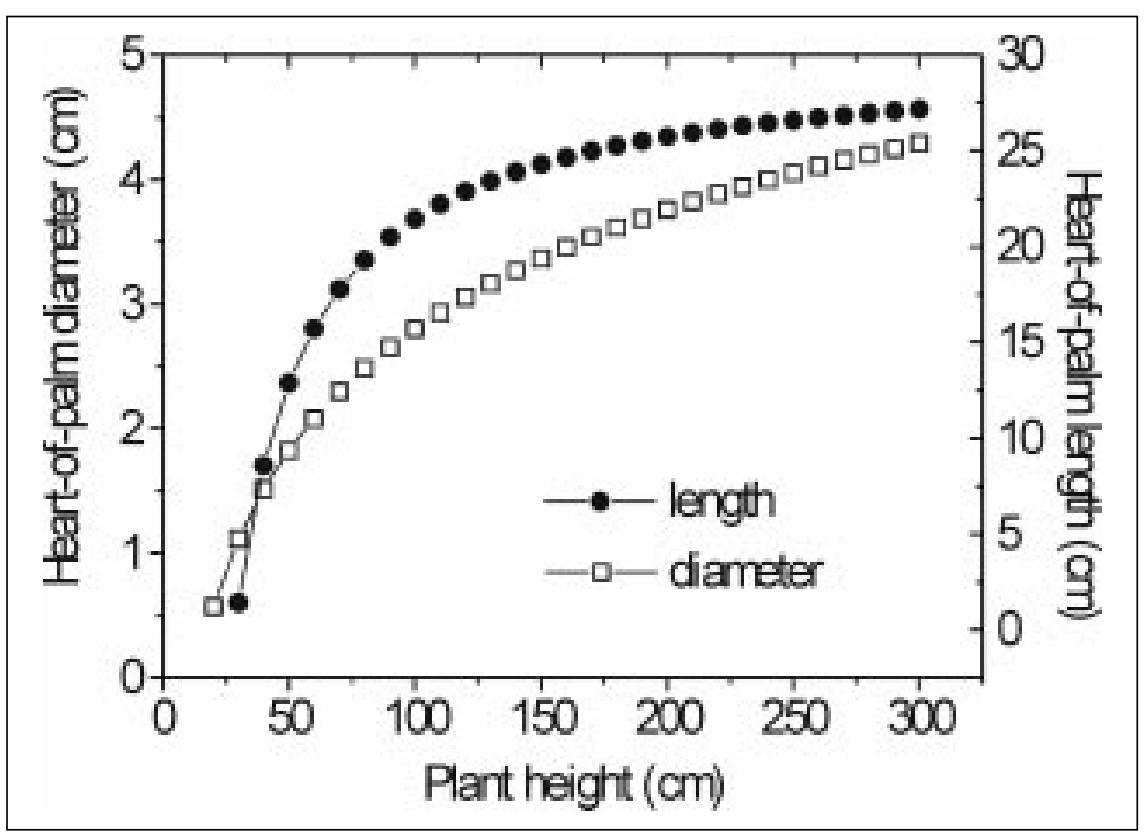

Figure 4. Heart-of-palm diameter and length of King palm, as a function of plant height. Pariqueraçu (Brazil), IAC, 2000.

increased plant height. Therefore, there is a gradual increment in palm heart diameter with age, or in other words, with plant development, probably until a maximum is reached for that species at those growing conditions. It was reported, for Euterpe and Bactris, that heart-of-palm diameter is a function of internal leaves number and leaflets number and dimensions, with limits imposed by the species utilized (Bovi et al., 1991b; 1992; 1993).

Due to the intricate relationship among growth and palm heart weight and dimensions, the adequate harvesting size could be established based also in market type. When heart-of-palm is preserved in large containers, timing for harvesting should be established based on maximum yield in the minimum time. Therefore, harvesting should be done on plants $200-300 \mathrm{~cm}$ tall. In the conditions of this experiment this could be accomplished only after 40 months after planting, on $50 \%$ of the plant population. At that interval, maximum estimated yield would be around 1.11 
$\mathrm{kg} /$ plant $(61 \%$ heart-of-palm and $39 \%$ edible stem), with heart-of-palm diameter over $4 \mathrm{~cm}$. Minimum yield is estimated to be $0.75 \mathrm{~kg} /$ plant $(47 \%$ heart-of-palm and $53 \%$ edible stem), with diameter around $3.7 \mathrm{~cm}$. Taken in account plant density and mortality, this would amount $1612 \mathrm{~kg} / \mathrm{ha}$ (total yield) 3.5 years after planting. Considering the same class growth rate ( $\mathrm{C} 1$ and $\mathrm{C} 2)$, next harvesting would be expected to be done one year after the first.

Nonetheless, most of the heart-ofpalm production is processed in smaller cans or jars (300 g, drained weight), and from the processing standpoint, heartof-palm diameter should not be larger than $3 \mathrm{~cm}$, due to packing difficulties. As a fact, palm heart with diameter between 2 and $2.5 \mathrm{~cm}$ should be preferred, because it allows the packing of six to eight pieces per jar or can. Besides the better appearance, pieces like that provide uniform cooking and acidification and have, as a rule, a more homogenous texture (Berbari \& Paschoalino, 1997). Considering the models provided here, adequate palm heart diameter is reached when palms are from 80 to $115 \mathrm{~cm}$ height. At that height, heart-of-palm length will be between 19.41 and $22.57 \mathrm{~cm}$, and its weight will vary from 90 to $138 \mathrm{~g} / \mathrm{plant}$ (heart-of-palm) and 134 to $223 \mathrm{~g} /$ plant (edible soft stem). By that standard and in these experimental conditions, harvesting could be done from 22 to 30 months after harvesting, in $50 \%$ of the plant population. Palm heart yield is estimated in $292 \mathrm{~g} / \mathrm{plant}$ or $506 \mathrm{~kg} / \mathrm{ha}$ at 2 years after planting. The next harvesting would be expected to be done one year after the first.

It could be noted that yield in the second condition (small diameter) is much lower than in the first (large diameter) and, as the price paid for both products is similar, the decision of what market type to attend is basically economic.

This study highlights the need to maximize King palm growth rate, utilizing superior genetical material and providing conditions to enhance growth, as adequate seedling production and selection, correct crop management and irrigation, as well as organic and inorganic fertilization. Faster grower palms, besides promote precocious and larger yield, are less prone to premature dead due to the action of competitors and predators.

\section{LITERATURE CITED}

BERBARI, S.A.G.; PASCHOALINO, J.E. Industrialização do palmito pupunha. Campinas: Instituto de Tecnologia de Alimentos, 1997. 45 p. (Manual Técnico 15).

BOVI, M.L.A.; GODOY JR., G. Juvenile-mature correlations in heart of palm plants. Revista Brasileira de Genética, Ribeirão Preto, v. 14, n. 3, p. 739-751, 1991a.

BOVI, M.L.A.; GODOY JÚNIOR, G.; SAES, L.A. Correlações fenotípicas entre caracteres da palmeira Euterpe edulis Mart. e produção de palmito. Revista Brasileira de Genética, Ribeirão Preto, v. 14, n. 1, p. 105-121, 1991 b.

BOVI, M.L.A.; SAES, L.A.; GODOY JÚNIOR, G. Correlações fenotípicas entre caracteres não destrutíveis e palmito em pupunheiras. Revista Turrialba, v. 42, n. 3, p. 382-390, 1992.

BOVI, M.L.A.; GODOY JÚNIOR, G.; CAMARGO, S.B., SPIERING, S.H. Seleção precoce em pupunheiras (Bactris gasipaes H.B.K.) para produção de palmito. In: CONGRESO INTERNACIONAL SOBRE BIOLOGIA, AGRONOMIA E INDUSTRIALIZACION DEL PIJUAYO, 4., 1993, Iquitos. Anais.... San José: UFCR, 1993. p. 177-195.

BOVI, M.L.A.; VIEIRA, S.R.; SPIERING, S.H.; MONTEIRO, S.M.G.; GALLO, P.B. Relações entre crescimento de pupunheira e alguns parâmetros físicos do solo. In: CONGRESSO BRASILEIRO DE CIÊNCIA DO SOLO, 26., 1997, Rio de Janeiro. Anais..., Viçosa: SBCS, 1997. 4 p. (CD-ROM).

BOVI, M.L.A. Expansão do cultivo da pupunheira para palmito no Brasil. Horticultura Brasileira, Brasília, v. 15, Suplemento, p. 183-185, 1997.

BOVI, M.L.A. Cultivo da palmeira real australiana visando a produção de palmito. Campinas: Instituto Agronômico, 1998. 26 p. (Boletim Técnico 172). CLEMENT, C.R.; BOVI, M.L.A. Padronização de medidas de crescimento e produção em experimentos com pupunheira para palmito. Acta Amazonica, Manaus, v. 30, n. 3, p. 349-362, 2000. CLEMENT, C.R. Growth and genetic analysis of pejibaye (Bactris gasipaes Kunth, Palmae) in Hawaii. Honolulu: University of Hawaii, 1995. 221 p. (Dissertação doutorado)

CODEX ALIMENTARIUS. Codex standard for canned palmito. Standard 144, Codex Standards for Processed Fruits and Vegetables and Edible Fungi. Codex Standards, v. 2, Suppl. 1, p. 11-23, 1985.

FERREIRA， V.L.P.; BOVI, M.L.A.; ANGELUCCI, E.; FIGUEIREDO, I.B.; YOKOMIZO, Y.; SALES, A.M. Estudo dos palmitos das palmeiras e do híbrido de Euterpe edulis Mart. e Euterpe oleracea Mart. II. Avaliações físicas e químicas. Coletânea ITAL, Campinas, v. 12, n. 1, p. 243-254, 1982a.

FERREIRA, V.L.P.; BOVI, M.L.A.; CARVALHO, C.R.L.; MANTOVANI, D.M.B. Composição química e curvas de titulação de acidez do palmito pupunha (Bactris gasipaes H.B.K.) de diversas localidades. Coletânea ITAL, Campinas, v. 20, n. 1, p. 96-104, 1990.

FERREIRA, V.L.P.; GRANER, M.; BOVI, M.L.A.; DRAETTA, I.S.; PASCHOALINO, J.E.; SHIROSE, I. Comparação entre os palmitos de Guilielma gasipaes Bailey (pupunha) e Euterpe edulis Mart. (juçara). I. Avaliações físicas, organolépticas e bioquímicas. Coletânea do ITAL, Campinas, v. 12, n. 1, p. 255-272, 1982 b.
GALETTI, M; FERNANDEZ, J.C. Palm heart harvesting in the Brazilian Atlantic forest: changes in industry structure and the illegal trade. Journal of Applied Ecology, v. 35, n. 2, p. 294-301, 1998. HARDON, J.J. Oil palm breeding - Introduction. In: CORLEY, R.H.V.; HARDON, J.J.; WOOD, B.J. (eds.) Oil Palm Research. New York: Elsevier, 1982. p. 89-108.

HARTLEY, C.W.S. The oil palm (Elaeis guineensis Jacq.), 2 ed. London: Longman, Tropical Agriculture Series. 1977. 806 p.

JONES, D.L. Palms throughout the world. Washington: The Smithsonian Institution Press, 1994. $410 \mathrm{p}$. JORGE, J.A.; BOVI, M.L.A. Influência das propriedades físicas e químicas do solo no crescimento da palmeira pupunha. In: CONGRESSO BRASILEIRO DE FRUTICULTURA 13., 1994, Salvador. Resumos expandidos. Salvador: SBF, 1994. p. 1145-1146.

LEPSCH, I.F.; SARAIVA, I.R.; DONZELI, P.L.; MARINHO, M.A.; SAKAI, E.; GUILLAUMON, J.R.; PFEIFER, R.M.; MATTOS, I.F.A.; ANDRADE, W.J.; SILVA, C.E.F. Macrozoneamento das terras da região do rio Ribeira de Iguape, SP. Campinas: Instituto Agronômico, 1990. 181 p. (Boletim Científico 19).

LORENZI, H. Palmeiras no Brasil: exóticas e nativas. Nova Odessa: Editora Plantarum, 1996. 303 p. MORA-URPÍ, J.; WEBER, J.C.; CLEMENT, C.R. Peach palm. Bactris gasipaes Kunth. Promoting the conservation and use of underutilized and neglected crops. 20. Rome: Institute of Plant Genetics and Crop Plant Research, Gaterleben and International Plant Genetic Resources Institute, 1997. 83 p.

MUNIZ-MIRET, N; VAMOS, R; HIRAOKA, M.; MONTAGNINI, F.; MENDELSOHN, R.O. The economic value of managing the acai palm (Euterpe oleracea Mart.) in the floodplains of the Amazon estuary, Para, Brazil. Forest Ecology and Management, v. 87, n. 1-3, p. 163-173, 1996.

ORLANDE, T.; LAARMAN, J.; MORTIMER, J. Palmito sustainability and economics in Brazil's Atlantic coastal forest. Forest Ecology and Management, v. 80, n. 1-3, p. 257-265, 1996.

PENA-CLAROS, M.; ZUIDEMA, P. Demographic limitations to the sustainable extraction of palm heart from Euterpe precatoria in two forest types in Bolivia. Ecologia en Bolivia, v. 33, n. 3, p. 3-21, 1999.

RAIJ, B.; QUAGGIO, J.A.; SILVA, N.M. Extraction of phosphorus, potassium, calcium and magnesium form soils by an ion-exchange resin procedure. Communication in Soil Science Plant Analysis, v. 17, p. 549-566, 1986.

SECRETARIA, M.I.; MARAVILLA, J.N. Response of hybrid coconut palms to application of manures and fertilizers from field planting to full-bearing stage. Plantations, reserche, développement, v. 4, n. 2, p. 126-138, 1997.

SIMMONDS, N.W. Principles of crop improvement. New York: Longman, 1979. 408 p. SOUZA, L.S.; DINIZ, M.S.; CALDAS, R.C. Correção da interferência da variabilidade do solo na interpretação dos resultados de um experimento de cultivares/clones de mandioca. Revista Brasileira de Ciência do Solo, Campinas, v. 20, n. 4, p. 441-445, 1996.

STEEL, R.G.D.; TORRIE, J.H. Principles and Procedures of statistics. New York: McGraw-Hill, 1980. $632 \mathrm{p}$.

TABORA, P.C.JR.; BALICK, M.J.; BOVI, M.L.A.; GUERRA, M.P. Hearts of Palm (Bactris, Euterpe and others). In: J.P. WILLIAMS (ed.). Pulses and Vegetables. London: Chapman and Hall, 1993. p.193-218. 